\title{
Biochar Mitigates Greenhouse Gas Emissions from an Acidic Tea Soil
}

\author{
Hong Wang ${ }^{1}$, Huaiting Yi ${ }^{1}$, Xiao Zhang ${ }^{1}$, Wei Su${ }^{1}$, Xinwei Li', \\ Yaojun Zhang ${ }^{2 *}$, Xiang Gao ${ }^{3}$ \\ ${ }^{1}$ College of Resource and Environment, Anhui Science and Technology University, Chuzhou, China \\ ${ }^{2}$ School of Life Sciences, Henan University, Kaifeng, China \\ ${ }^{3}$ Sinochem Agriculture Holdings, China
}

Received: 18 October 2018

Accepted: 18 November 2018

\begin{abstract}
Acidic tea soil is an important greenhouse gas (GHG) emission source.Few studies have been done to investigate the impact of alkaline biochar addition on acidicsoil GHG emissions. We carried out a 40-day aerobic incubation experiment to investigate the alkaline biochar amendment on carbon dioxide $\left(\mathrm{CO}_{2}\right)$, methane $\left(\mathrm{CH}_{4}\right)$, and nitrous oxide $\left(\mathrm{N}_{2} \mathrm{O}\right)$ emissions from an acidic tea soil under $\mathrm{N}$ application. Soil samples were collected in the $0-15 \mathrm{~cm}$ layers from a tea orchard of Purple Mountain in Nanjing, Jiangsu Province, China. The results showed that biochar amendment significantly increased soil $\mathrm{pH}$, dissolved organic carbon (DOC), total dissolved nitrogen (TDN), and the ratio of DOC/TDN at the end of incubation. $\mathrm{N}$ fertilization increased all three GHG emissions. In contrast, biochar amendment significantly decreased soil $\mathrm{CO}_{2}$ and $\mathrm{N}_{2} \mathrm{O}$ emissions by $7.2-9.3 \%$ and $36.3-44.2 \%$, respectively. Although the interaction of biochar and $\mathrm{N}$ fertilizer on soil $\mathrm{CO}_{2}$ and $\mathrm{CH}_{4}$ emissions were not obvious, $\mathrm{N}_{2} \mathrm{O}$ emissions were significantly affected by their interaction. Consistent with $\mathrm{CO}_{2}$ and $\mathrm{N}_{2} \mathrm{O}$ emissions, the net GWP was significantly decreased by biochar addition. Overall, the present study suggests that biochar amendment could be used as an effective management mitigating soil GHG emissions and the net GWP from the acidic tea field soil.
\end{abstract}

Keywords: biochar, carbon dioxide, nitrous oxide, methane, net GWP

\section{Introduction}

Carbon dioxide $\left(\mathrm{CO}_{2}\right)$, methane $\left(\mathrm{CH}_{4}\right)$ and nitrous oxide $\left(\mathrm{N}_{2} \mathrm{O}\right)$ are three major greenhouse gases (GHGs) and all of them have increased sharply since 1750 due to human activities. Over a 100 -year time period,the global warming potential (GWP) of $\mathrm{CH}_{4}$ and $\mathrm{N}_{2} \mathrm{O}$ are

*e-mail: njauyjzhang@163.com
34 and 298 times greater than $\mathrm{CO}_{2}$, respectively [1]. Besides, $\mathrm{N}_{2} \mathrm{O}$ in the atmosphere is also playing an important role in damaging the stratospheric ozone layer [2]. Agricultural soil is an important source of anthropogenic GHG emissions due to a mass of nitrogen (N) fertilizer application [3]. Reducing agricultural soil GHG emissions has gained attention worldwide because of the GWP of GHGs and maintains the sustainbility of agricultural production [4]. Thus, there is an urgency to look for an effective method that can mitigate agricultural soil GHG emissions. 
Tea (Camellia sinensis), an important cash crop, is planted widely in China [5-6]. In addition, as a leaf-harvested crop, Nnutrient is vital for increasing tea yield and quality [7]. Therefore, tea fields in China always receive large amounts of nitrogen fertilizer. For instance, annual $\mathrm{N}$ fertilizer application rates have always exeeded $450 \mathrm{~kg} \mathrm{~N} \mathrm{ha}{ }^{-1}$ (or even more than $1200 \mathrm{~kg} \mathrm{~N} \mathrm{ha}^{-1}$ )on tea plantations in China [6, 8-9], which obviously exceeds the suggested rate of $250-375 \mathrm{~kg} \mathrm{~N} \mathrm{ha}^{-1} \mathrm{yr}^{-1}$ for high yields of tea plantations [10]. Undoubtedly, such high $\mathrm{N}$ fertilizer application could result in environemtal problems such as soil acidification and high rates of soil GHGs (especially $\mathrm{N}_{2} \mathrm{O}$ ) emissions [8, 11]. Long-term soil acidity could supress tea production while enhancing soil $\mathrm{N}_{2} \mathrm{O}$ emissions, thus making a negative impact on tea plantation ecosystems $[6,12]$. It was reported that soil GHGs (especially $\mathrm{N}_{2} \mathrm{O}$ ) emissions from tea fields induced by $\mathrm{N}$ ferlization, were much higher than those from other crop fields [6, 13-14].

Biochar amendment to a field, always with high $\mathrm{pH}$ and rich carbon content, has been well reported as an effective management strategy to counteract soil acidification for sustainable agriculture while reducing soil GHG emissions [15-21]. Biochar plays an important role in accommodating soil processes (e.g., soil nitrification, denitrification and organic matter mineralization), thus it affects soil $\mathrm{C}$ and $\mathrm{N}$ cycling [22]. The effect of biochar addition on soil GHG emissions has been investigated deepy, but the results were inconsistent. Generally, previous studies showed that soil $\mathrm{N}_{2} \mathrm{O}$ emissions could be reduced significantly with biochar addition, particularly in acidic soils [2326]. However, the effect of biochar amendment on soil $\mathrm{CO}_{2}$ and $\mathrm{CH}_{4}$ emisions is a different controversy [27-29]. Thus resulting in poor understanding of how biochar addition affects soil GHG emissions and the related GWP.

Here we examined the effect of an alkaline biochar addition on GHG emissions from an acidic tea soil with $\mathrm{N}$ application. Our aim was to evaluate the biochar effect on $\mathrm{CO}_{2}, \mathrm{CH}_{4}$ and $\mathrm{N}_{2} \mathrm{O}$ emissions and the related GWP from acidic tea soil. We hypothesized that 1) biochar would result in a significant reduction in $\mathrm{N}_{2} \mathrm{O}$ emissions through increasing soil $\mathrm{pH}$ and 2) biochar could be used as an effective supplement to reduce acidic tea soil GWP.

\section{Materials and Methods}

\section{Soil Sampling and Biochar}

Soil samples were collected in the $0-15 \mathrm{~cm}$ layers from a tea orchard of Purple Mountain in Nanjing, Jiangsu Province, China $\left(32^{\circ} 07^{\prime} \mathrm{N}, 118^{\circ} 86^{\prime} \mathrm{E}\right)$. Thirtysix soil cores were collected randomly and mixed homogenously to are presentative soil sample. After being air-dried for 15 days, any visible plant detritus
Table 1. Soil physicochemical properties $($ mean \pm SE) before the incubation.

\begin{tabular}{|c|c|}
\hline Property & Value \\
\hline Clay $(\%)$ & $40.67 \pm 1.09$ \\
\hline Sand $(\%)$ & $49.17 \pm 1.01$ \\
\hline Silt (\%) & $10.16 \pm 0.36$ \\
\hline Total C $\left(\mathrm{g} \mathrm{kg}^{-1}\right)$ & $13.91 \pm 0.34$ \\
\hline Total N $\left(\mathrm{g} \mathrm{kg}^{-1}\right)$ & $1.35 \pm 0.02$ \\
\hline Soil $\mathrm{C} / \mathrm{N}$ ratio & $10.34 \pm 0.37$ \\
\hline $\mathrm{pH}, \mathrm{H}_{2} \mathrm{O}(1: 2.5)$ & $4.69 \pm 0.03$ \\
\hline Dissolved organic $\mathrm{C}\left(\mathrm{mg} \mathrm{kg}^{-1}\right)$ & $98.03 \pm 5.12$ \\
\hline Dissolved organic $\mathrm{N}\left(\mathrm{mg} \mathrm{kg}^{-1}\right)$ & $24.02 \pm 1.80$ \\
\hline $\mathrm{NH}_{4}^{+}-\mathrm{N}\left(\mathrm{mg} \mathrm{kg}^{-1}\right)$ & $15.82 \pm 1.96$ \\
\hline $\mathrm{NO}_{3}^{-}-\mathrm{N}\left(\mathrm{mg} \mathrm{kg}^{-1}\right)$ & $29.97 \pm 2.00$ \\
\hline Bulk density $\left(\mathrm{g} \mathrm{cm}^{-3}\right)$ & $1.27 \pm 0.02$ \\
\hline
\end{tabular}

and fragments were picked out by hand, and the soil samples were then sieved at $2 \mathrm{~mm}$. Soil physicochemical properties are shown in Table 1. The biochar used in this study was produced from wheat straw through lowtemperature pyrolysis $\left(500^{\circ} \mathrm{C}\right)$ and also ground to pass through a 2-mm sieve. Biochar was characterized by a $\mathrm{pH}$ of 10.9. Total $\mathrm{N}$ content was $6.1 \mathrm{~g} \mathrm{~kg}^{-1}$ and organic $\mathrm{C}$ content was $467.2 \mathrm{~g} \mathrm{~kg}^{-1}$.

\section{Incubation}

Four treatments were performed in our experiment: control, biochar amendment (+Biochar), $\mathrm{N}$ application (+Nitrogen), and biochar plus $\mathrm{N}$ amendment $(+B \&+N)$. Each treatment included four replicates. For each treatment, $100 \mathrm{~g}$ of air-dried soil was added to a conical flask with $250 \mathrm{ml}$ space, receiving $4 \mathrm{~g}$ (4\% w/w)biochar added to each soil, and biochar were thoroughly mixed with the soil. Then distilled water was used to meet the desired soil water content of $60 \%$ water-holding capacity (WHC). Thereafter, the flaskes were pre-incubated for one week in order to stabilize the microbial activity and thus avoid the undesired microbial peaks [30]. Pre-incubation and the subsequent incubation were performed without light at room temperature $\left(25 \pm 1^{\circ} \mathrm{C}\right)$ for 40 days. Flasks were hermetically sealed with para film to prevent water evaporation. Every 2 or 3 days, flasks were weighed and distilled water was used to replenish water losses if necessary. At the same time, another group was set up and incubated for measuring soil mineral $\mathrm{N}\left(\mathrm{NH}_{4}^{+}-\mathrm{N}, \mathrm{NO}_{3}^{-}-\mathrm{N}\right)$ content changes at days $3,5,10,20$ and 40 .

\section{Greenhouse Gases Measurement}

Gas sampling was taken by a gas-tight syringe from the heads pace of the flasks after pre-incubation. Gas 
sampling was measured after $1,2,3,4,5,6,7,9,10$, $12,15,18,20,22,25,30,35$ and 40 days of incubation. For each measurement, the heads pace air in the flasks was thoroughly mixed with ambient air for $1 \mathrm{~min}$ at a rate of $200 \mathrm{~mL} \mathrm{~min}{ }^{-1}$ before gas sampling. The flasks were then capped promptly with silicone rubber stoppers, which gave an airtight seal, then kept with butyl rubber $2 \mathrm{~h}$ for gas sampling. The ambient air gas sample was used as the initial concentration for calculating the GHG emission rate. After this period the air in the heads pace of incubation flasks were sampled to determine the gas concentration increase. Then flasks were flushed
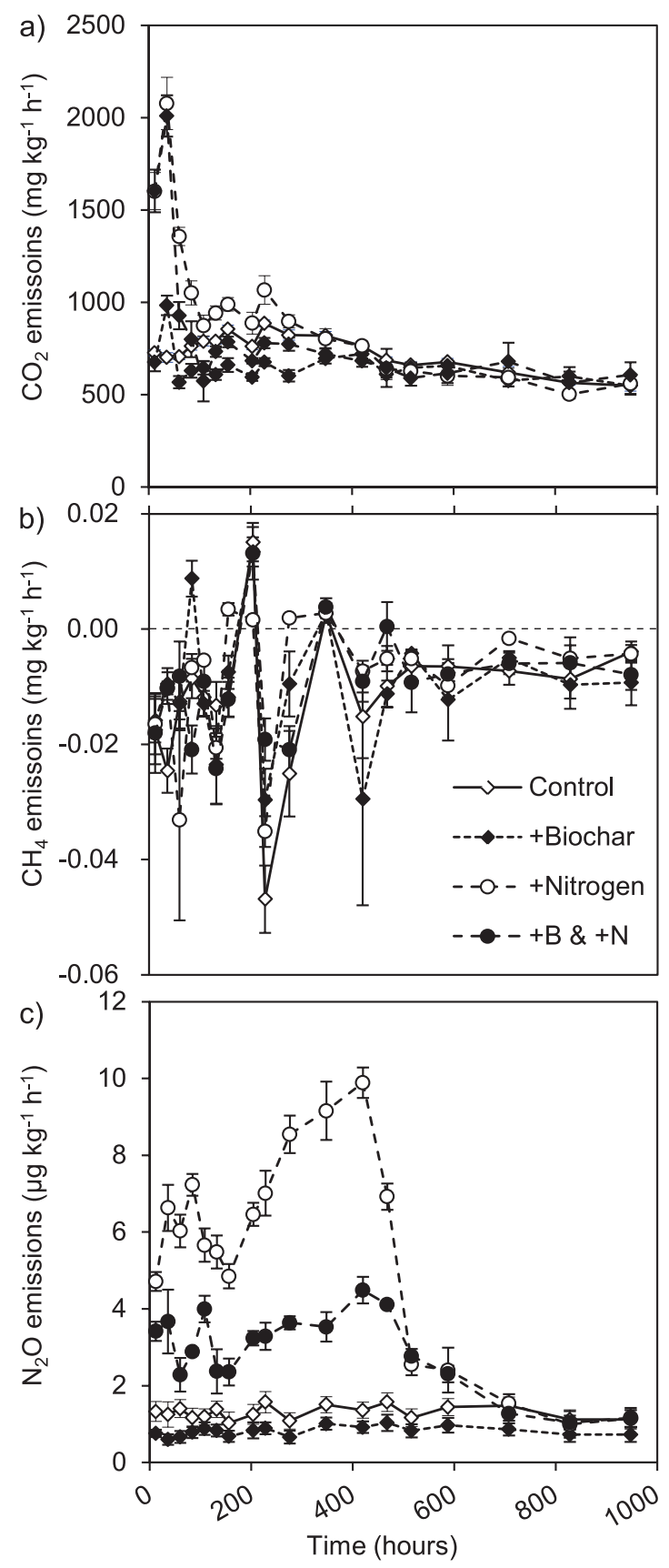

Fi. 1. Hourly $\mathrm{CO}_{2}$ a), $\mathrm{CH}_{4}$ b) and $\mathrm{N}_{2} \mathrm{O}$ c) emissions during the 40-day incubation. The error bars indicate the standard errors of means $( \pm \mathrm{SE})$. with ambient air again and kept open after sampling.

Gas samples were analyzed with a gas chromatograph (Agilent 7890A, USA) equipped with two detectors within 6 hours: a flame ionization detector (FID) and an electron capture detector (ECD). $\mathrm{CO}_{2}$ and $\mathrm{CH}_{4}$ were detected using FID, and $\mathrm{N}_{2} \mathrm{O}$ was detected using ECD. $\mathrm{CO}_{2}$ was reduced to $\mathrm{CH}_{4}$ by hydrogen, which occurred in a nickel catalytic converter at $375^{\circ} \mathrm{C}$. Purified gas of nitrogen and a gas mixture of argon-methane (5\%) were used as the carrier gases for $\mathrm{CO}_{2}$ and $\mathrm{N}_{2} \mathrm{O}$, respectively.

\section{Soil Chemical Analysis}

After incubation, soil samples were extracted with $2 \mathrm{M} \mathrm{KCl}$ solution (soil/water ratio of 1:5) and shaken at $200 \mathrm{rev} \mathrm{min}^{-1}$ for $1 \mathrm{~h}$ at $25^{\circ} \mathrm{C}$. Then the soil extracts, after filtration, were used for analyzing: 1) soil dissolved organic carbon (DOC) and total dissolved nitrogen (TDN) (Shimadzu TOC-V csh, TNM-1, Kyoto, Japan), and 2) soil mineral $\mathrm{N}\left(\mathrm{NO}_{3}{ }^{-}-\mathrm{N}\right.$ and $\left.\mathrm{NH}_{4}^{+}-\mathrm{N}\right)$ contents following the two wavelength ultraviolet spectrometry by an ultraviolet spectrophotometer (HITA-CHI U-2900, Japan) [24]. Soilor biochar $\mathrm{pH}$ was analyzedin a volume ratio of $1: 2.5$ (soil or biochar/water) by a PHS-3 C mv/pH detector (Shanghai, China).

\section{Data Analysis}

Production of $\mathrm{CO}_{2}, \mathrm{CH}_{4}$ and $\mathrm{N}_{2} \mathrm{O}$ were calculated assuming constant rates of production. The net GWP of GHGs was calculated by converting the production of $\mathrm{CH}_{4}$ and $\mathrm{N}_{2} \mathrm{O}$ into $\mathrm{CO}_{2}$ equivalents. The net GWP for a 100 -year time horizon with inclusion of climatecarbon feedback was calculated using a radiative forcing potential relative to $\mathrm{CO}_{2}$ of 34 for $\mathrm{CH}_{4}$ and 298 for $\mathrm{N}_{2} \mathrm{O}$ [1]. Differences in cumulative GHGs emissions and chemical characteristics as affected by biochar, fertilizer $\mathrm{N}$ and their interactions were examined with a twoway analysis of variance (ANOVA). Linear or nonlinear regression analyses were conducted to examine the dependence of $\mathrm{CO}_{2}, \mathrm{CH}_{4}$ and $\mathrm{N}_{2} \mathrm{O}$ emissions on soil mineral $\mathrm{N}$ contents. Statistical analysis of data was performed using SPSS software version 21 for Windows (SAS, 2013). The data are presented as means \pm standard error (SE).

\section{Results and Discussion}

\section{$\mathrm{CO}_{2}$ Emissions Influenced by Biochar and $\mathrm{N}$ Addition}

Soil $\mathrm{CO}_{2}$ emissions showed a distinct variation with incubation progress (Fig. 1a). The highest $\mathrm{CO}_{2}$ emission was observed during the primary stage of the incubation and then decreased gently, which was probably due to the availability of soil labile C. Large amounts of $\mathrm{CO}_{2}$ emissions in the initial phase of incubation are probably due to heterotrophic consumption of soil 
availability labile $\mathrm{C}$ caused by biochar addition, while with exhaustion of labile $\mathrm{C}$ resulting in slow rates of $\mathrm{CO}_{2}$ emissions in the final stages of incubation [24, 28]. A priming effect of biochar addition on $\mathrm{CO}_{2}$ emissions resulting in an emissions peak within three days was observed in this study. $\mathrm{CO}_{2}$ showed higher emissions at the beginning incubation period with $\mathrm{N}$ and biochar amendment than in the following incubation period. Furthermore, relative to no fertilizer $\mathrm{N}$ addition (control and + Biochar treatments), $\mathrm{N}$ addition (+Nitrogen and $+\mathrm{B}$ and $+\mathrm{N}$ treatments) stimulated the initial $\mathrm{CO}_{2}$ fluxes and the cumulative emissions, likely due to the $\mathrm{CO}_{2}$ produced from urea hydrolysis [22]. On the contrary, biochar addition decreased soil $\mathrm{CO}_{2}$ emissions by $7.17 \%$ and $9.29 \%$ with or without $\mathrm{N}$ application, respectively (Table 2). Short-term pulses of $\mathrm{CO}_{2}$ emissions stimulated by biochar amendment have been reported, and ascribed this to additions of labile $\mathrm{C}$ accompanied with biochar amendment [24, 31-34]. Soil $\mathrm{CO}_{2}$ emissions decreased gradually after the emission peaks, and then slowed gently during the last few days of incubation.

Over the whole incubation period, cumulative $\mathrm{CO}_{2}$ emissions averaged 664.10, 602.38, 744.14, and $690.74 \mathrm{~g} \mathrm{~kg}^{-1}$ soil for the control, +Biochar, +Nitrogen, and $+\mathrm{B}$ and $+\mathrm{N}$ treatments, respectively (Table 2). Biochar addition significantly decreased soil $\mathrm{CO}_{2}$ emissions while $\mathrm{N}$ application reduced its depression effect $(-7.17 \%$ and $-9.29 \%$ under the $\mathrm{N}$ or no $\mathrm{N}$ application treatments, respectively). In the present study, biochar amendment decreasing the cumulative soil $\mathrm{CO}_{2}$ emissions was probably due to the reduction of soil availability $\mathrm{N}$ (e.g., soil $\mathrm{NH}_{4}^{+}-\mathrm{N}$ decreased by $30.7 \%$ and $55.8 \%$ with or without $\mathrm{N}$ application, respectively; soil $\mathrm{NO}_{3}{ }^{-}-\mathrm{N}$ decreased by $49.7 \%$ and $63.3 \%$ with or without $\mathrm{N}$ application, respectively) and its stable property and $\mathrm{C}$ sequestration $[15,35]$.

\section{$\mathrm{CH}_{4}$ Emissions Response to Biochar and $\mathrm{N}$ Addition}

Different from $\mathrm{CO}_{2}$ emissions, soil $\mathrm{CH}_{4}$ emissions were shown highly variable with no distinct pattern (Fig. 1b). During the whole incubation period, N application significantly stimulated soil $\mathrm{CH}_{4}$ emissions mainly due to the urea hydrolysis for methane bacteria [22]. Although there were several sporadic positive $\mathrm{CH}_{4}$ emission peaks observed in all treatments, the majority of soil $\mathrm{CH}_{4}$ emissions were negative, which means the soil showed as a net $\mathrm{CH}_{4}$ oxidation sink. In addition, relative to $\mathrm{CO}_{2}$ emissions, soil $\mathrm{CH}_{4}$ emissions fluctuated strongly and showed an opposite effect following biochar amendment associate with or without $\mathrm{N}$ application (Fig. 1, Table 2). Biochar amendment could improve soil aeration and decrease an oxic conditions in soil, thus decreasing $\mathrm{CH}_{4}$ production and increasing its oxidation. Further more, labile $\mathrm{C}$ in soils is also obviously influencing methane oxidation [36].

Cumulative $\mathrm{CH}_{4}$ emissions were affected by $\mathrm{N}$ application but unaffected by biochar addition

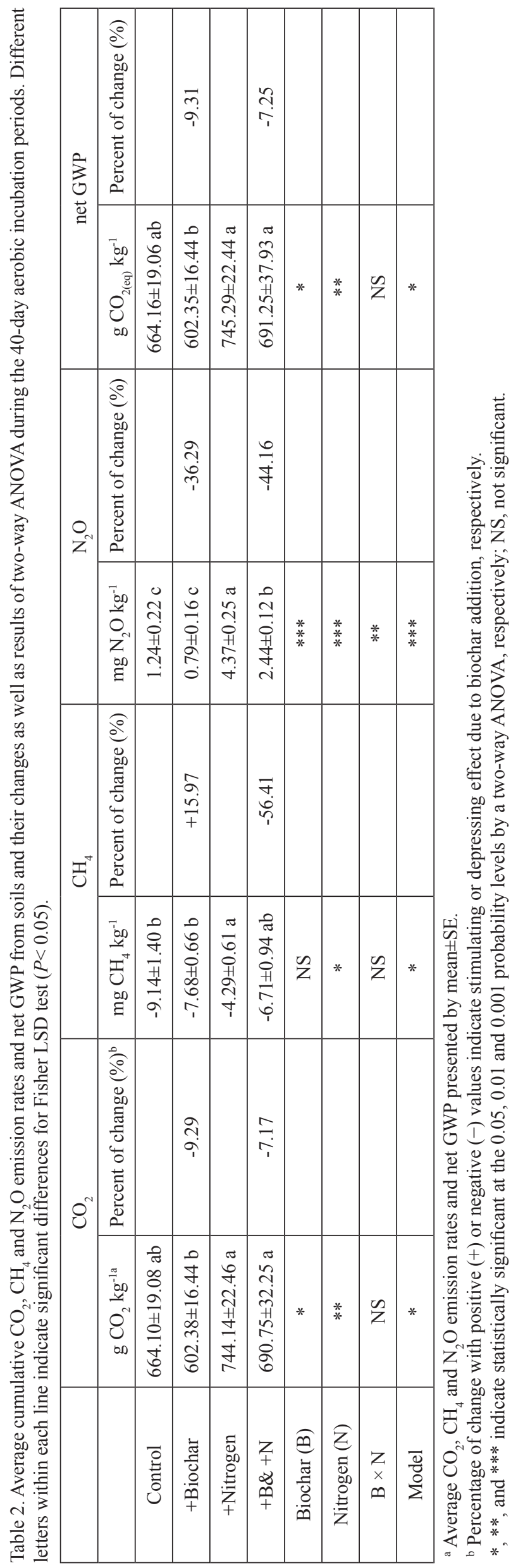


(Table 2). Biochar increased $\mathrm{CH}_{4}$ emissions by $15.97 \%$ under the control treatment but decreased by $56.41 \%$ with $\mathrm{N}$ application. The inconsistent effects of biochar (with or without $\mathrm{N}$ addtion) on soil $\mathrm{CH}_{4}$ emissions should give more attention, with a focus on better identification and quantification of the carbon input by biochar.

\section{Effects of Biochar and N Addition on $\mathrm{N}_{2} \mathrm{O}$ Emissions}

$\mathrm{N}_{2} \mathrm{O}$ emissions followed a significant temporal variation during the first 20-dayincubation period, and the greates $\mathrm{tN}_{2} \mathrm{O}$ emissions (up to $9.89 \mu \mathrm{g} \mathrm{kg} \mathrm{kg}^{-1} \mathrm{~h}^{-1}$ ) occurred at day 18 followed by the $\mathrm{N}$ addition (Fig. 1c). Afterward, $\mathrm{N}_{2} \mathrm{O}$ emissions declined rapidly and were kept steadily low until the end of incubation. $\mathrm{N}_{2} \mathrm{O}$ emissions were depressed significantly by biochar addition in the first 20-day incubation (-51.1\%), but no obvious effect until the incubation finished $(-0.9 \%)$ with $\mathrm{N}$ application. The short-term $\mathrm{N}_{2} \mathrm{O}$ emission pulses induced by $\mathrm{N}$ addition indicated that $\mathrm{N}_{2} \mathrm{O}$ emission peaks occur rapidly and shortly in response to fertilizer $\mathrm{N}$ application [24, 37-38]. The cumulative $\mathrm{N}_{2} \mathrm{O}$ emissions averaged $1.24,0.79,4.37$, and $2.44 \mathrm{mg} \mathrm{kg}^{-1}$ soil for the control, +Biochar, +Nitrogen, and $+\mathrm{B}$ and $+\mathrm{N}$ treatments, respectively. Biochar addition showed a more significantly inhibiting effect on $\mathrm{N}_{2} \mathrm{O}$ emissions with $\mathrm{N}$ application $(-44.16 \%)$ rather than no $\mathrm{N}$ addition (-36.29\%). Biochar amendment decreasing soil $\mathrm{N}_{2} \mathrm{O}$ emissions has also been reported in previous studies [24-26], which are mainly attributed to changes in soil $\mathrm{C} / \mathrm{N}$ ration and aeration, soil microbial community composition and size structures, and microbial enzymes and processes (e.g., nitrification, denitrification) involved in $\mathrm{N}$ cycling in soil [25, 39-40]. In general, $\mathrm{N}_{2} \mathrm{O}$ emissions were significantly influenced by $\mathrm{N}$ fertilizer, biochar and their interaction from acidic tea soil in the present study (Table 2).

\section{Overall Global Warming Potential}

Net GWP ( $\mathrm{t} \mathrm{CO}_{2}$ equivalent $\mathrm{ha}^{-1}$ ) was calculated in our study in order to evaluate the mitigation effects of biochar amendment on the combined climatic impacts of $\mathrm{CO}_{2}, \mathrm{CH}_{4}$ and $\mathrm{N}_{2} \mathrm{O}$ emissions in the acidic teasoil. The net GWP was significantly affected by biochar and $\mathrm{N}$ application but not their interaction (Table 2). $\mathrm{N}$ addition resulted in the greatest GWP (745.29 $\mathrm{g} \mathrm{CO}_{2(\mathrm{eq})} \mathrm{kg}^{-1}$ ), while biochar amendment decreased by $7.25 \%$. The least GWP (602.35 g $\mathrm{CO}_{2(\mathrm{eq})} \mathrm{kg}^{-1}$ ) was foundin the treatment where soil was only amended with biochar (+Biochar), which was depressed by $9.31 \%$ compared with control. The net GWP was positive for all treatments, suggesting that the acidic tea soil acted as an important GHG source. Here, the net GWP significantly increased with $\mathrm{N}$ fertilization while decreasing with biohcar amendment throughout the incubation period. The obvious decrease in net

GWP with biochar amendment was potentially attributed to its $\mathrm{C}$ sequestration [15], and thus indicating that biochar amendment could be used as an effective management tool for mitigating the net GWP from the acidic tea field soil.

\section{Soil Characteristic Changes Regulating GHGs Emissions}

Biochar and $\mathrm{N}$ application significantly affected soil $\mathrm{pH}$ while showing no interactions (Table 3 ). The addition of biochar increased soil $\mathrm{pH}$ by more than 1 unit compared with the control treatment. Soil mineral $\mathrm{N}$ contents were significantly influenced by both biochar and $\mathrm{N}$ addition (Table 3). Soil $\mathrm{NH}_{4}^{+}-\mathrm{N}$ and $\mathrm{NO}_{3}{ }^{-}-\mathrm{N}$ contents increased significantly with $\mathrm{N}$ application but decreased with biochar addition, which means that biochar amendment could inhibit soil mineralization and nitrification. $\mathrm{NO}_{3}{ }^{-} \mathrm{N}$ increased with incubation time while $\mathrm{NH}_{4}^{+}-\mathrm{N}$ decreased sharply with $\mathrm{N}$ application. $\mathrm{NH}_{4}^{+}-\mathrm{N}$ contents changed rarely and were

Table 3. Soil characteristics as well as results of two-way ANOVA after the 40-day incubation (mean $\pm \mathrm{SE})$. Different letters within each line indicate significant differences for Fisher LSD test $(P<0.05)$.

\begin{tabular}{|c|c|c|c|c|c|c|}
\hline & $\mathrm{pH}$ & $\mathrm{NH}_{4}{ }^{+}-\mathrm{N}\left(\mathrm{mg} \mathrm{kg}^{-1}\right)$ & $\mathrm{NO}_{3}-\mathrm{N}\left(\mathrm{mg} \mathrm{kg}^{-1}\right)$ & $\mathrm{DOC}\left(\mathrm{mg} \mathrm{kg}^{-1}\right)$ & $\mathrm{TDN}\left(\mathrm{mg} \mathrm{kg}^{-1}\right)$ & $\mathrm{DOC} / \mathrm{TDN}$ \\
\hline Control & $4.62 \pm 0.03 \mathrm{c}$ & $20.94 \pm 0.93 \mathrm{c}$ & $38.76 \pm 5.03 \mathrm{bc}$ & $126.97 \pm 10.62 \mathrm{c}$ & $29.48 \pm 2.75 \mathrm{c}$ & $4.32 \pm 0.07 \mathrm{~b}$ \\
\hline+ Biochar & $5.72 \pm 0.02 \mathrm{a}$ & $9.26 \pm 0.63 \mathrm{~d}$ & $14.24 \pm 2.10 \mathrm{c}$ & $177.90 \pm 7.74 \mathrm{ab}$ & $36.42 \pm 1.42 \mathrm{~b}$ & $4.90 \pm 0.22 \mathrm{a}$ \\
\hline+ Nitrogen & $4.04 \pm 0.01 \mathrm{~d}$ & $43.03 \pm 1.10 \mathrm{a}$ & $135.28 \pm 13.41 \mathrm{a}$ & $152.65 \pm 12.00 \mathrm{bc}$ & $39.64 \pm 2.38 \mathrm{~b}$ & $3.84 \pm 0.11 \mathrm{c}$ \\
\hline+ B\& $+\mathrm{N}$ & $5.29 \pm 0.14 \mathrm{~b}$ & $29.82 \pm 1.80 \mathrm{~b}$ & $68.01 \pm 13.32 \mathrm{~b}$ & $188.48 \pm 12.55 \mathrm{a}$ & $47.01 \pm 1.76 \mathrm{a}$ & $4.00 \pm 0.13 \mathrm{bc}$ \\
\hline Biochar (B) & $* * *$ & $* * *$ & $* *$ & $* *$ & $* *$ & $*$ \\
\hline Nitrogen (N) & $* * *$ & $* * *$ & $* * *$ & NS & $* * *$ & $* * *$ \\
\hline B $\times \mathrm{N}$ & $\mathrm{NS}$ & $\mathrm{NS}$ & $\mathrm{NS}$ & $\mathrm{NS}$ & $\mathrm{NS}$ & NS \\
\hline Model & $* * *$ & $* * *$ & $* * *$ & $* *$ & $* * *$ & $* * *$ \\
\hline
\end{tabular}

$*, * *$, and *** indicate statistically significant at the $0.05,0.01$ and 0.001 probability levels by a two-way ANOVA, respectively; NS, not significant. 
kept low in the control and biochar treatments compared with the $\mathrm{N}$ treatments.

Soil $\mathrm{N}_{2} \mathrm{O}$ is primarily produced through soil nitrification and denitrification processes, which are highly dependent on soil characteristics, such as soil mineral $\mathrm{N}$ contents and $\mathrm{pH}$ [41-42]. Soil $\mathrm{pH}$, which has been considered a central factorinflucing $\mathrm{N}$ transformations [43], was increased by biochar additionin acidic soils and might be an important factor
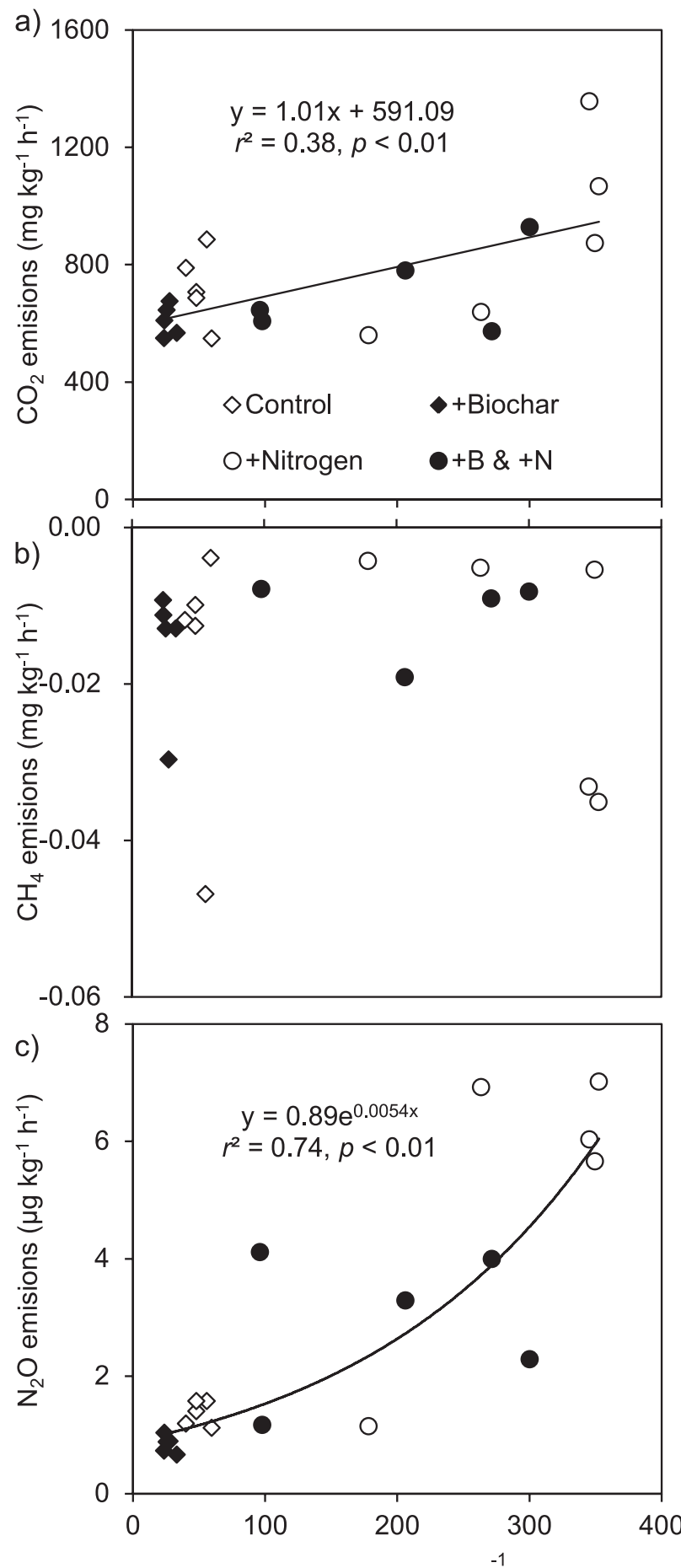

Fig. 2. Soil $\mathrm{CO}_{2}$ a), $\mathrm{CH}_{4}$ b) and $\mathrm{N}_{2} \mathrm{O}$ c) emissions dependent on soil mineral $\mathrm{N}\left(\mathrm{NH}_{4}^{+}-\mathrm{N}+\mathrm{NO}_{3}^{-}-\mathrm{N}\right)$ contents during the 40-day incubation. decreasing $\mathrm{N}_{2} \mathrm{O}$ emissions in the present study (Table 3). High soil $\mathrm{pH}$ induced by bichar addition decreased the $\mathrm{N}_{2} \mathrm{O}$ emissions, probably due to the high soil $\mathrm{pH}$ destoried activity of the functional $\mathrm{N}_{2} \mathrm{O}$ reductase enzyme, thus depressing the denitrification progress $[25,43-44] . \mathrm{N}_{2} \mathrm{O}$ emissions depend significantly on soil mineral $\mathrm{N}$ in the present study (Fig. 2c), which is in accordance with previous studies [45]. In addition, Singh et al. [38] proposed that soil $\mathrm{N}$ immobilization by the sorption capacity of biochar could also reduce $\mathrm{N}_{2} \mathrm{O}$ emissions. We found that soil $\mathrm{NH}_{4}^{+}$and $\mathrm{NO}_{3}^{-}$ decreased by $30.7-55.8 \%$ and $49.7-63.3 \%$, respectively, suggesting that $\mathrm{N}$ immobilization is an important factor influencing soil $\mathrm{N}_{2} \mathrm{O}$ emissions. Generally, soil $\mathrm{CO}_{2}$ and $\mathrm{N}_{2} \mathrm{O}$ emissions were signifcantly correlated with soil mineral $\mathrm{N}$ content during the incubation time (Figs 2a and c).

Biochar addition significantly affected soil DOC, TDN and the ratio of DOC/TDN over the whole incubation period. The interaction of biochar and $\mathrm{N}$ showed no effects on soil DOC, TDN and the ratio of DOC/TDN (Table 3).

\section{Conculsions}

This study showed that $\mathrm{N}$ additioncould increase all three GHG emissionsand the net GWP in acidic tea soil. However, biochar amendment significantly decreasedsoil $\mathrm{CO}_{2}$ and $\mathrm{N}_{2} \mathrm{O}$ emissions, and the related net GWP, while showing inconsistent results on $\mathrm{CH}_{4}$ emissions. The results suggest that biochar amendment (either alone or combined with $\mathrm{N}$ ) could be used as an effective method for reducing GHG emissions in acidic tea soil.

\section{Acknowledgements}

This work was supported by National Natural Science Foundation of China (41701283), the China Postdoctoral Science Foundation (2018M632760), the Natural Science Foundation of Anhui Province in China (16030701102), and the Key University Science Research Project of Anhui Province (KJ2016A173, KJ2019A0819).

\section{Conflict of Interest}

The authors declare no conflict of interest.

\section{References}

1. IPCC. In: Climate Change 2013: The Physical Science Basis. Contribution of Working Group I to the Fifh Assessment Report of the Intergovernmental Panel on Climate Change (eds T. F. Stocker et al.,) 5-14 (Cambridge University Press, 2013). 2013. 
2. RAVISHANKARA A., DANIEL J., PORTMANN R. Nitrousoxide $\left(\mathrm{N}_{2} \mathrm{O}\right)$ : The dominant ozone-depleting substance emitted in the $21^{\text {st }}$ century. Science 326 (5949), 123, 2009.

3. ZHANG W., DOU Z., HE P., JU X., POWLSON D., CHADWICK D., NORSE D., LU Y., ZHANG Y., WU L., CHEN X., CASSMAN K., ZHANG F. New technologies reduce greenhouse gas emissions from nitrogenous fertilizer in China. Proc. Natl. Acad. Sci.USA 110 (21), 8375, 2013.

4. JU X., XING G., CHEN X., ZHANG S., ZHANG L., LIU X., CUI Z., YIN B., CHRISTIE P., ZHU Z., ZHANG F. Reducing environmental risk by improving $\mathrm{N}$ management in intensive Chinese agricultural systems. Proc. Natl. Acad. Sci. USA 106 (9), 3041, 2009.

5. CHENG Y., WANG J., ZHANG J., MÜLLER C., WANG S.Mechanistic insights into the effects of $\mathrm{N}$ fertilizer applicationon $\mathrm{N}_{2} \mathrm{O}-$ emission pathways in acidic soil of a tea plantation. Plant Soil, 389 (1-2), 45, 2015.

6. YAO Z., WEI Y., LIU C., ZHENG X., XIE B. Organically fertilized tea plantation stimulates $\mathrm{N}_{2} \mathrm{O}$ emissions and lowers NO fluxes in subtropical China. Biogeosciences $\mathbf{1 2}$ (20), 5915, 2015

7. TOKUDA S., HAYATSU M. Nitrous oxide flux from a tea field amended with a large amount of nitrogen fertilizer and soil environmental factors controlling the flux. Soil Sci. Plant Nutr. 50 (3), 365, 2004.

8. FU X., LI Y., SU W., SHEN J., XIAO R., TONG C., WU J. Annual dynamics of $\mathrm{N}_{2} \mathrm{O}$ emissions from a tea field in southern subtropical China. Plant Soil Environ. 58 (8), 373, 2012.

9. LI Y., FU X., LIU X., SHEN J., LUO Q., XIAO R., LI Y., TONG C., WU J. Spatial variability and distribution of $\mathrm{N}_{2} \mathrm{O}$ emissions from a tea field during the dry season in subtropical central China. Geoderma 193-194, 1,2013

10. ZHU T., ZHANG J., MENG T., ZHANG Y., YANG J., MÜLlER C., CAI Z. Tea plantation destroys soil retention of $\mathrm{NO}_{3}^{-}$and increase $\mathrm{N}_{2} \mathrm{O}$ emissions in subtropical China. Soil Biol. Biochem. 73, 106, 2014.

11. HIRONO Y., NONAKA K. Nitrous oxide emissions from green tea fields in Japan: contribution of emissions from soil between rows and soil under the canopy of tea plants. Soil Sci. Plant Nutr. 58 (3), 384, 2012.

12. BAGgS E., SMALES C., BATEMAN E. Changing $\mathrm{pH}$ shifts the microbial source as well as the magnitude of $\mathrm{N}_{2} \mathrm{O}$ emission from soil. Biol. Fert. Soils, 46 (8), 793, 2010.

13. AKIYAMA H., YAN X., YAGI K. Estimations of emission factors for fertilizer-induced direct $\mathrm{N}_{2} \mathrm{O}$ emissions from agricultural soils in Japan: summary of available data. Soil Sci. Plant Nutr. 52, 774, 2006.

14. HAN W., XU J., WEI K., SHI Y., MA L. Estimation of $\mathrm{N}_{2} \mathrm{O}$ emission from tea garden soils, their adjacent vegetable garden and forest soils in eastern China. Environ. Earth Sci. 70 (6), 2495, 2013.

15. LEHMANN J. Bio-energy in the black. Front. Ecol. Environ. 5, 381, 2007.

16. WOOLF D., AMONETTE J., STREET-PERROTT A., LEHMANN J., JOSEPH S. Sustainable biochar to mitigate global climate change. Nat. Commun. 1 (5), 56, 2010.

17. WANG J., PAN X., LIU Y., ZHANG X., XIONG Z. Effects of biochar amendment in two soils on greenhouse gas emissions and crop production. Plant Soil, 360 (1-2), 287, 2012.

18. XIANG J., LIU D., DING W., YUAN J., LIN Y. Effects of biochar on nitrous oxide and nitric oxide emissions from paddy field during the wheat growth season. J. Clean. Prod. 104, 52, 2015.

19. SINGH R., BABU J., KUMAR R., SRIVASTAVA P., SINGH P., RAGHUBANSHI A. Multifaceted application of crop residue biochar as a tool for sustainable agriculture: An ecological perspective. Ecol. Eng. 77 (C), 324, 2015.

20. ZHANG D., YAN M., NIU Y., LIU X., VAN ZWIETEN L., CHEN D., BIAN R., CHENG K., LI L., JOSEPH S., ZHENG J., ZHANG X., ZHENG J., CROWLEY D., FILLEY T., PAN G. Is current biochar research addressing global soil constraints for sustainable agriculture? Agr. Ecosyst. Environ. 226, 25, 2016a.

21. SUBEDI R., BERTORA C., ZAVATTARO L., GRIGNANI C. Crop response to soils amended with biochar: expected benefits and unintended risks. Ital. J. Agron. 12 (2), 161, 2017.

22. VAN ZWIETEN L., KIMBER S., MORRIS S., DOWNIE A., BERGER E., RUST J., SCHEER C. Influence of biochars on flux of $\mathrm{N}_{2} \mathrm{O}$ and $\mathrm{CO}_{2}$ from ferrosol. Aust. J. Soil Res. 48, 555, 2010.

23. YANAI Y., TOYOTA K., OKAZAKI M. Effects of charcoal addition on $\mathrm{N}_{2} \mathrm{O}$ emissions from soil resulting from rewetting air-dired soil in short-term laboratory experiments. Soil Sci. Plant Nutr. 53 (2), 181, 2007.

24. WANG J., ZHANG M., XIONG Z., LIU P., PAN G. Effects of biochar addition on $\mathrm{N}_{2} \mathrm{O}$ and $\mathrm{CO}_{2}$ emissions from two paddy soils. Biol. Fert. Soils 47 (8), 887, 2011.

25. CAYUELA M., VAN ZWIETEN L., SINGH B., JEFFERY S., ROIG A., SÁNCHEZ-MONEDERO. Biochar's role in mitigating soil nitrous oxide emissions: A review and meta-analysis. Agr. Ecosyst. Environ. 191, 5, 2014.

26. NELISSEN V., SAHA B., RUYSSCHAERT G., BOECKX P. Effect of different biochar and fertilizer types on $\mathrm{N}_{2} \mathrm{O}$ and NO emissions. Soil Biol. Biochem. 70 (2), 244,2014.

27. ZIMMERMAN A., GAO B., AHN M. Positive and negative carbon mineralization priming effects among a variety of biochar-amended soils. Soil Biol. Biochem. 43, 1169,2011.

28. MAUCIERI C., ZHANG Y., MCDANIEL M., BORIN M., ADMAS M. Short-term effects of biochar and salinity on soil greenhouse gas emissions from a semi-arid Australian soil after re-wetting. Geoderma 307, 267, 2017.

29. OO A., SUDO S., AKIYAMA H., WIN K., SHIBATA A., YAMAMOTO A., SANO T., HIRONO, Y. Effect of dolomite and biochar addition on $\mathrm{N}_{2} \mathrm{O}$ and $\mathrm{CO}_{2}$ emissions from acidic tea field soil. PLoS ONE 13 (2), e0192235, 2018.

30. HUANG Y., ZOU J., ZHENG X., WANG Y., XU X. Nitrous oxide emissions as influenced by amendment of plant residues with different $\mathrm{C}: \mathrm{N}$ ratios. Soil Biol. Biochem. 36 (6), 973, 2004.

31. LUO Y., DURENKAMP M., DE NOBILI M., LIN Q., BROOKES P. Short term soil priming effects and the mineral is at ion of biochar following its incorporation to soils of different pH. Soil Biol. Biochem. 43 (11), 2304, 2011.

32. CHENG C., LIN T., LEHMANN J., FANG L., YANG Y., MENYAILO O., CHANG K., LAI J. Sorption properties for black carbon (wood char) after long term exposure in soils. Org. Geochem. 70 (5), 53,2014.

33. FANG Y., SINGH B., SINGH B., KRULL E. Biochar carbon stability in four contrasting soils. Eur. J. Soil Sci. 65 (1), 60,2014.

34. WANG J., XIONG Z., KUZYAKOV Y. Biochar stability in soil: meta-analysis of decomposition and priming effects. GCB Bioenergy, 8 (3), 512, 2016. 
35. LEHMANN J., GAUNT J., RONDON M. Bio-char sequestration in terrestrial ecosystems - A review. Mitig. Adapt. Strat. Gl. 11 (2), 403, 2006.

36. SULLIVAN B., SELMANTS P., HART S. Does dissolved organic carbon regulate biological methane oxidation in semiarid soils? Global Change Biol. 19 (7), 2149, 2013.

37. BEARE M., GREGORICH E., ST-GEORGES P. Compaction effects on $\mathrm{CO}_{2}$ and $\mathrm{N}_{2} \mathrm{O}$ production during drying and rewetting of soil. Soil Biol. Biochem. 41 (3), 611, 2009.

38. SINGH B., HATTON B., SINGH B., COWIE A., KATHURIA A. Influence of biochars on nitrous oxide emission and nitrogen leaching from two contrasting soils. J. Environ. Qual. 39 (4), 1224,2010.

39. CAYUELA M., SÁNCHEZ-MONEDERO M., ROIG A., HANLEY K., ENDERS A., LEHMANN J. Biochar and denitrification in soils: when, how much and why does biochar reduce $\mathrm{N}_{2} \mathrm{O}$ emissions? Sci. Rep. 3, 1732, 2013.

40. CASE S., MCNAMARA N., REAY S., STOTT A., GRANT H., WHITAKER J. Biochar suppresses $\mathrm{N}_{2} \mathrm{O}$ emissions while maintaining $\mathrm{N}$ availability in a sandy loam soil. Soil Biol. Biochem. 81, 178, 2015.
41. DAVIDSON E., KELLER M., ERICKSON H., VERCHOT L., VELDKAMP E. Testing a conceptual model of soil emissions of nitrous and nitric oxides. Bio Science 50 (8), 667, 2000.

42. WRAGE N., VELTHOF G., VAN BEUSICHEM M., OENEMA O. Role of nitrifier denitrification in the production of nitrous oxide. Soil Biol. Biochem. 33 (12), 1723, 2001.

43. MØRKVED P., DORSCH P., BAKKEN L. The $\mathrm{N}_{2} \mathrm{O}$ product ratio of nitrification and its dependence on long-term changes in soil pH. Soil Biol. Biochem. 39 (8), 2048,2007.

44. LIU B., MØRKVED P., FROSTEGÅRD Å., BAKKEN L. Denitrification gene pools, transcription and kinetics of $\mathrm{NO}, \mathrm{N}_{2} \mathrm{O}$ and $\mathrm{N}_{2}$ production as affected by soil $\mathrm{pH}$. FEMS Microbiol. Ecol. 72 (3), 407,2010.

45. ZHANG Y., LIN F., JIN Y., WANG X., LIU S., ZOU J. Response of nitric and nitrous oxide fluxes to $\mathrm{N}$ fertilizer application in greenhouse vegetable cropping systems in southeast China. Sci. Rep. 6, $20700,2016$. 